\title{
ESSENCE OF BUDDHISM: RELIGIOUS TOLERANCE AND LOVE FOR NATURE, ESSENTIAL FOR HUMAN EXISTENCE
}

Rita Rana*

\begin{abstract}
This work aims to present the essence and the importance of Buddhism for human existence along with a brief introduction of the founder of Buddhism and the impact and influence of this religion on the human society. A fact that life or all that exists is dynamic or changing and that which does not exist is actually permanent or static. The focus of this work is to show that the ultimate truth is through experience, religion, the awareness of religioustolerance and its benefits to the human world. Another point of focus is on the path towards Enlightenment which is believed to be by detachment in life rather than attachment. It highlights the 'Teachings of Buddha' to have an open mind and sympathetic heart that gives light and warmth to wisdom and compassion.
\end{abstract}

Key Words: Human existence, Buddhism, Religious - Tolerance, Ignorance, Nirvana, prejudice, Essence, Wisdom

\section{Introduction}

The question and curiosity puzzles many. What is Buddhism in reality? Is it a religion, a philosophy or just a way of life? It is the noble truth that Buddhism cannot be put in one single category. Different people living at different times and places have given different labels and interpretations to Buddhism. For example, some say Buddhism is a product of its Indian environment or an outgrowth of another kind of Indian religious teachings. To some it appears to be a superstitious practice, to some a label to be used for temporal gain, to others it is an ancient or old fashion, some take it as a scientific discovery and yet others take Buddhism as a system of thought only for intellectuals. Instead of the limitations of the scientific mind, Buddhism is beyond science in acceptance of a wider field of knowledge. It admits knowledge arising from the sense organs as well as personal experiences gained through mental culture. This system is both scientific and practical and it involves dispassionate observation of emotional and mental states. It has a complete

* Rana is an Associate Professor of the Department of English in Patan Multiple Campus, T.U. Patandhoka. 
system of mental culture concerned with gaining insight into the nature of things which leads to complete self-realization of the ultimate truth- Nirvana or Nibbana (57).

The fourth largest religion in the world is Buddhism which refers to the teachings of Gautam Buddha, who was born from Queen Mayadevi in the $5^{\text {th }}$ century BC in Lumbini of Kapilvastu, West Nepal. Buddhists take refuge in Buddha, the Dharma (his teachings) and the Sangha (the Buddhists community). The man who was born a prince, who had all he needed in life. A pure descent and was the heir to the throne at the age of sixteen. Had all the luxurious upbringings in a palace where he had his family, extremely good looking in person with a beautiful wife and a son. He was a cheerful person full of dignity and grace. Despite of all this in his life, he felt himself to be like a bird with no freedom of thought and movement' trapped in a golden cage. 'The Four Sights' that he viewed during his visit outside the palace was what made him realize and understand about the reality of life, which he then understood to be that man, is subject to life and death (5). This was the man who was known as the Buddha, after attaining The Enlightenment and understanding the actual Truth of life. Gautam Buddha, 'The awakened one' was the Founder of Buddhism. Buddhism is nothing other than the noble truth. It is an intellectual approach to reality. Buddha's realization of the universal problem did not come through a purely intellectual and a rational process, but through mental development and purification (63). The goal or the main aim of Buddhist practice is to attain enlightenment (wisdom/knowledge) and selfrealization from the teachings of Buddha the Awakened One.

Buddhism therefore is an experience which is actually the 'Enlightenment' and the universal truth, the true nature of life as disclosed by the teachings of Buddha that not only started a religion, but inspired the blossoming of a whole civilization. Non-attachment is a way to attain enlightenment, according to Buddhism. Its belief is that most of the troubles of life, caused due to attachment. Thus detachment was the path adopted by Buddha for knowledge and truth in life. People are well versed with certain rites and rituals yet the understanding of the teachings of this religion are seen to be lacking within, that leads to ignore the noble teachings of Buddha and to introduce many baseless beliefs. Many ill-founded traditions and mockery are projected towards this religion, due to lack of the true spiritual development which gives wisdom and understanding. Thoughts of the selfish and misguided workers gives an impression of encouragement into superstitious beliefs and dependence on charms and omens, again because of ignorance towards one's own religion and its essence that can make one a pray to the snares of conversion, as mentioned by Dhammanand (105). In reality, this is not accepted and tolerated in Buddhism. Buddha's message of non-violence 
and peace, love and compassion, of tolerance and understanding, truth and wisdom, of respect and regard for life and freedom from selfishness and tolerance for others religion and beliefs was delivered 2500years ago, which still stands good for today and will stand forever as truth is an eternal message to mankind even today and for the coming days.

\section{Buddhism and its link with Nature:}

Buddhism being a significant religious dimension that has been linked to ecological concern as well, regards Buddhist principles and attitude towards nature as eco-friendly and attuned to natural environment. All the essential elements for a relationship to the natural world characterized by respect, humility, care and compassion are provided within the Buddhists principles. As seen how, in comparison to the mainstream Christianity as being anthropocentric, Lynn White commends Buddhism for its holistic, egalitarian worldview and its environmentally friendly style of life. The Buddhists over the world have promoted White's such positive evaluation of Buddhist principles as they encourage ecological awareness and responsibility through various Buddhist ethics. Buddhism is seen to lay high emphasis on the preservation of ecology that manifests in the way trees and forests are treated.

Trees play a significant role in the entire life cycle of Gautam Buddha. As Daniel Henning observes that "Gautam Buddha himself was born in the forest under a 'sal' tree (shorearobusta). He then attained enlightenment in the forest under the 'Bodhi' tree (ficusreligiosa) and he taught in the forest and even passed away in the forest"(12). Gautam Buddha frequently dwelt in forests, both during his spiritual quest and even after his enlightenment. In the early Buddhist texts, plants and trees are always treated with respect and kindness. In these texts descriptions of nature and nature- based metaphors, include scenes of sermons and meditations under trees and deep forests. In the Pali discourse Lord Buddha often instructed his disciples to seek out forest dwellings as these places are most favorable for purifying the mind. Among the greatest disciples of Buddha many opted the forest dwelling as ideal environment to practice their religious life. To cite the examples of the forest dwelling monks, the Thai scholar monk P.A. Payutto writes that " throughout the history of Thailand Buddhism has seen the forest as a teacher of mind and spirit and that living within such a natural environment engenders a great sense of happiness and well-being."(22) Many of the Buddhist principles are nature -oriented and support an environmental ethics and worldview of deep ecology. 
Today modern culture of excessive consumption has led to the systematic depletion of nature because of the use of various technologies that pose serious threat to ecology. According to Gross the main question today is what values and practices would convince people to consume and produce less when they have the technological ability to consume and produce more. As viewed by Gross, the non harming principles in Buddhist ethics to be most favorable for the ecological concern in today's technological world. When one realizes that over consumption and reproduction is harmful one can be obliged to limit such activities (336). The example provided through the simple lifestyle practiced by the Buddhist monks shows how to live non-acqisitively. Stephanie Kaza echoes the view of Gross and writes, "Perhaps the most useful of Buddhist teachings is the insight into the emptiness of the ego self. This view holds the key to releasing attachment to the constant self-inflating messages of consumerism." ( qtd. in Christopher Chapple 522) As given in her article, 'Towards a Buddhist Environmental Ethic' Rita Gross, states that, "The reason why the environmental concerns are now so grave is because the humans have the technologies to consume and reproduce in such ways that, if not moderated, seem almost certain to destroy the ecological basis for human life"(335). Therefore the non harming principles within the teachings of Buddhism can be taken as the best solution to save nature and the human world.

Another aspect of Buddhist teachings that relates to environmental and human concern is the concept of interdependence and interconnection. Such teachings representing a nondualistic, non-hierarchal, holistic world view conjoin all sentient beings, humans and animals. Highlighting the dynamics of interdependent nature of life, the late Thai monk Buddhadasa Bhikkhu writes, "The entire cosmos is a cooperative. The sun, moon and stars live together as a cooperative. Similarly it is true for humans and animals, trees and the earth. When we realize that the world is a mutual, interdependent, cooperative enterprise, then we can build a noble environment (qtd. in Swearer 127). Such a celebration of interdependence invites us to establish a relationship with the world and helps us to limit our anthropocentric view." According to Gross, we cannot intervene or rearrange the ecosystem without affecting everything around us and the human interference in the ecosystem cannot be a pursuit of 'progress' and 'growth' which are the two things that many view as ideals (338).

The Four Noble Truths of the Buddha's teachings are equally significant to mankind as they very clearly show the ecological concern. These Nobel Truths examine the fundamental human conditions: sufferings, the cause of human sufferings, the end of suffering and the path that leads to end of the sufferings. Peter Daniels in his essay, 'Buddhism and the 
Transformation to Sustainable Economics', elaborates how Buddhist worldview as depicted in these Noble Truths is potential pathways for environmental sustainability. Daniel also explains how these Noble Truths have become more relevant in the Western consumerism economics:

'The desire to satisfy systemic, constantly regenerated wants is a major motive of our lives, thoughts and actions, and permeates almost every aspect of the society. We really seek sustained satisfaction but, instead are attracted to and become "addicted" to an irrational process of short-term satisfaction of dynamic and endless wants (159).'

The Four Noble Truths are a starting point to identify the environmental harm caused by the gap between the never ending wants and satisfaction in the modern materialistic society of human world. According to Danial, the harm, "results from extensive biophysical intervention in the ecosphere in search of materials and energy" (159). Therefore, only when every human adopts a moderate life style and has a non-exploitative and a non-aggressive attitude towards nature as espoused in the Buddhist teachings, that mankind as a whole can live in harmony with nature and can highly contribute to mitigate ecological crisis that have stemmed from human activities. This can be possible only if the simple Buddhist ideals of non-violence and harmless practice is extended by all mankind, and then alone can it be possible to help change the global environmental crisis of sustainability in human life.

\section{Benefits and Impact of Buddhism on Human Civilization}

Buddhism can be an effective civilizing force and of great importance in this modern world. It awakens self-respect and feelings of self responsibility towards the people and the nation. It fosters spiritual progress by appealing to man's own thinking powers. The sense of tolerance is promoted by being free from religious and national narrowness and fanaticism. It refines the mind to be clear and sober and brings the feelings of self-reliance as the belief of Buddhism is that the destiny of man lies in his own hands. He can develop his own energy and insight to reach his own desired goal. (50-51) Buddhism today has satisfied the spiritual needs of nearly one third of mankind for almost over two thousand years. As said by K.Shri. Dhammananda in his work, 'What Buddhists Believe' (59), that the appeal of Buddhism is equally strong as ever even today for its teachings lift the horizon of human efforts to a higher level beyond a mere dedication to mans needs and appetites. The most effective appeal of Buddhism is that it is realistic and gives a realistic view of life and the world on the whole. It does not entice people into living in a fool's paradise, nor does it frighten people with all kinds of imaginary fears and feelings of guilt. 
Buddhism talks exactly what we and the world around us is and shows the way to freedom, peace and happiness. This vision of Buddha has the tendency to attract the different intellectuals who have exhausted their minds. Today it can be taken as one of the most effective vehicle to be saved from reaching against the moral standards taught by any religion. Buddhism is believed to be the religion of humanity. In the period that man is overwhelmed by his success within the control of the material universe, man might like to look back and take stock of the achievements he has made in controlling the most difficult of all phenomena, 'his own self'. It is in Buddhism that the modern man will find an answer to his numerous doubts and problems (061). Buddhism today, appeals even to the West because it has no dogmas and satisfies both reason and heart alike. It encourages and insists on self-reliance along with tolerance for others and the other religions and also embraces modern scientific discoveries if they are for constructive purposes. It is according to Buddhism that man alone is the creator for his present life and is the sole designer of his own destiny. This essence and nature of peace and compassion has spread all over the world. The effect of Buddhism is such that all those who came under its influence, readily accepted and adopted it as a new way of religious life that has served man's hopes and aspirations for human welfare all over the world.

Buddhism denies the existence of a permanent, god created soul or an unchanging entity that transmigrates from one life to another (98). According to Buddhist theory everything is changeable in the universe. What exists is changeable and what is not changeable does not exist in reality (85). Life as seen is liable to change continuously from birth to death. Every moment going through various changes .An experience at every stage, experiencing success and failure, loss and gain, experience of honor and contempt, praise and blame, happiness and sorrow, disappointment and satisfaction, fear and hope and so on. The waves of emotions carry us up and throw us down with new waves rising and falling every now and then. This is life, the waves of love, hate, power, pride and desire, the ever restless ocean of existence. How can one expect any stand or stability in this moving wave of life . There is the experience of rise and fall, joys and disappointments, success and failure amidst the sickness, desperation and death in human life with the experience of friends changing to foes, close ones going at a distance, an unending flux of becoming is the real system of the universe. So is the human mind, never still, always moving, looking back, remembering, accumulating knowledge, constantly changing. Thought is time and time is movement, time is measurement — comparing and measuring all the time in life (6).

Importance of Religious-Tolerance in human life: two options in life for religious-tolerance: 
First, is to promote religious-tolerance which means to work towards a culture which allows everyone to follow their own desired path or chose a spiritual and religious one without any hindrance, harassment or suppression of any kind from anyone. This includes the people whose beliefs are very different to our own, having different attitudes, thoughts and understandings towards other people and their religion.

Secondly, it can be to continue living in a world saturated with religious-intolerance, where we can experience more religiously based wars, terrorism and civil disturbances as seen in the last few decades in the various places like Afghanistan, Iraq, India, Israel, Cyprus, Nigeria, North Ireland, Philippines, Pakistan, SriLanka, New York City, the Pentagon, Pennsylvania and others. The root cause of the 9-11 terrorist attack can also be taken as an example of religious hatred and intolerance. Such people take religious tolerance to be a weakness of faith or disregard for the welfare of others. This attitude makes them condemn all those who disagree to accept their faith and religion. Therefore it is your own decision to choose the kind of a world you want to live in, you yourself and your coming generation.

The main concept of Buddhism is 'My Journey is everybody's journey'. Living in a multiracial and a multi-cultural society we must know how to regard and respect other religions, how to adjust and accommodate them with appropriate place within our own religion which is very important for a peaceful existence within the human world. Buddhists is a religious group that accepts and appreciates the reasonable teachings of any other religion. It respects other people's views and appreciates their practices without having any religious prejudices. Those who are unable to accept and appreciate the ways of other religions, the least they can do is to maintain silence and refrain from any undue criticisms. This is called sympathetic understanding and is known as religious tolerance, which is one of the most important factors for human existence.

The unbearable mistakes made by the people due to religious- intolerance can be understood, through the study of how religions have influenced people over the time. Therefore to cultivate the real religious tolerance and to eradicate fear, suspicion and insecurity from the mind of the people, we should sincerely follow our respective religion to live a peaceful life. This is the essence of the teachings of Buddhism, which can make us understand the basis of our religion, reform our attitude towards other religions, that encourages to be honest, sincere, truthful, broad-minded and kind enough to practice and accept any religion. Buddhism is the religion that has never in the history, applied any violence or force to encourage others into it, that is the major cause of its popularity and is appreciated by every 
cultured man almost everywhere in the world, irrespective of his religious belief, without harboring any prejudices. It is a teaching of open-minded and sympathetic heart that gives the light and warms the whole universe with its rays of wisdom and compassion. This can be known as the righteous way of living rather than religion or philosophy.

Finally it can be said that Buddhism believes that Karma (action) keeps people bound to this world and has an important role in the cycle of births and deaths, similar to Hinduism. Buddha believed that desire is the root cause of suffering. Keeping desire out of our mind can lead in the cessation of suffering and can result in liberation-Nirvana which has an important place in every religion, however, every religion has a different notion. Teachings of Buddha shows that there wasn't a constant soul but a collection of feelings, perceptions, senses and other intangibles that made up all living beings. The ultimate goal for the Buddhists, therefore is something more abstract like ending the sufferings by escaping the cycle of rebirths and entering into a state of Nirvana, which itself is an abstract concept. Taking Nirvana to mean Paradise or Heaven is a common misconception. Buddhism thus believes that world peace can only be achieved if we first establish peace within our mindsBuddhists believe that people can live in peace harmony if we abandon negative emotions such as anger in our minds and cultivate positive emotions such as love and compassion.

\section{WORK-CITED}

Ambedkar,B.R. The Buddha and His Dhamma Nagpur: Buddha Bhoomi Pub, 1997

Blocker, T Jean."Varieties of Religious Involvement and Environmental Concerns: Testing the Lynn White Thesis.” Journal for the Scientific Study of Religion, 28. 4 (1989): 509-517.

Brown, Phil. "The Role of Buddhism in Enhancing Environmental Philosophy and Psychology in the West Today." Buddhism and Ecocrisis. Buddha Net 2000. 15 March $2017<$ https//www.buddhanet.net/mag eco.htm>

Conze, Edward. Buddhism: Its Essence and Development. Harper Torch book, 1975.

Daniel, Henning. A Manual for Buddhism and Deep Ecology. Special Edition by the World Buddhist University, 2006. 2 March 2017. http://www.buddhanet.net/pdf file/deepecology.pdf p. 12

Dhammanand, Shri.K. What Buddhist Believe. The Corporate body of the Buddha's Educational Foundation.55, Hang Chow S.Rd. Sec. 1.Tapei Taiwan 1993.

Gross, Rita M. "Toward a Buddhist Environmental Ethic." Journal of the American Academy of Religion, 65.2 (1997): 333-353.

Harvey, Peter. “The Selfless Mind,” Delhi: Curzon Press, 1955. 
Leaman, Oliver. Key Concepts in Eastern Philosophy. Routledge, 1999.

Murthy, T.R.The Central Philosophy of Buddhism: A Study of Madhyamik System : London. George Allenand Unnin : 1955.

Radhakrishna, S. and Charles, A.Moore. A Source Book in Indian Philosophy. Princeton University Press, 1997. 